\title{
A Survey of Iranian Middle School Teachers’ Desire for Staff Development with a Focus on Competencies to Teach Gifted Students
}

\author{
Afsaneh Kalbasi, PhD Scholar (Corresponding author) \\ Department of Educational Sciences, Faculty of Educational Sciences and Psychology \\ University of Isfahan, Isfahan, Iran
}

Tel: 98-091-3303-4336Ｅ-mail: kalbasiafsaneh@gmail.com

\begin{abstract}
Ahmadreza Nasr
Department of Educational Sciences, Faculty of Educational Sciences and Psychology University of Isfahan, Isfahan, Iran
\end{abstract}

\author{
Ahmad Abedi \\ Department of Educational Sciences, Faculty of Psychology \\ University of Isfahan, Isfahan, Iran
}

Ebrahim Mirshajafari

Department of Educational Sciences, Faculty of Educational Sciences and Psychology University of Isfahan, Isfahan, Iran

Received: July 12, 2012 Accepted: October 29, 2012 Published: November 1, 2012 doi:10.5296/jse.v2i4.2084

URL: http://dx.doi.org/10.5296/jse.v2i4.2084

\begin{abstract}
The purpose of the current study was two-fold. First, to determine the level of teachers' desire for professional development in competencies needed to teach gifted learners, and second, to identify differences in the level of teachers' desirability as it is related to a number
\end{abstract}


of independent measures (gender, primary teaching assignment, years of teaching, and in-service training hours in gifted education).

The population studied in this study included all middle school teachers of gifted schools in Isfahan, Iran. Of the 200 teachers in this population, 105 returned a completed survey. Participants were asked to rate their level of desire for professional development in 28 competencies identified as necessary by the University of Virginia to teach gifted learners.

After the pilot study, data were analyzed by SPSS. Cronbach's alpha coefficient for this scale was set to be .96. For data analysis, descriptive statistics and one sample t-test and one-way ANOVA were used. Results indicated that teachers have significantly high desirability for professional development in competencies that is related to knowing cognitive and social/emotional needs of gifted learners and adapting their teaching to foster creativity or critical thinking. Competencies related to foundations in gifted education such as the significance of historical events to the field or the contributions of key leaders whose work has direct bearing on the field were perceived by teachers to be the least desirable.

No significant differences were found in teacher's desire for professional development related to, primary teaching assignment, years of full time teaching experience, and hours accrued through in-service training in gifted education.

Significant differences were found in five of the 28 competencies among teachers who differed in their gender. The results suggest that variability in participants' desire for professional development does exist. However, on the whole, differences in desirability were not related to differences in the independent measures.

Key words: Staff development, Competency, Gifted education 


\section{Gifted Education in Iran}

Iranian formal programming efforts to serve students of high academic ability began in the mid-twentieth century. In 1968, Hoshdar Public School designed a system for early grade promotions for those who exhibited outstanding academic ability.

The review of literature includes a history of gifted education, which is rife with examples of policy changes that have significantly affected the range of programs for gifted learners. Literature related to best practice in gifted education such as differentiated curriculum and instruction are also examined. Discourse between excellence and equity also has created a tension regarding the education of gifted and talented students.

In Iran, gifted students are defined as those whose abilities and potential for accomplishment are so outstanding that they require special programs to meet their educational needs. These students possess talents and abilities that differ from those of their peers to such a degree that differentiated educational programs should be provided to nurture their growth and development. The identification of these students is based on the premise that they need and can benefit from specifically planned educational services differentiated from those provided by the general educational experience. In Iranian educational system, throughout the school districts, certain schools designated to offer special and enhanced curriculum to identified gifted and talented students. Although many gifted programs include good teaching strategies and differentiation, numerous programs lack higher-level thinking, problem solving, and adjustment to individual differences skills. Without a program of services that differs from what is available in the regular educational program, the superior talents and abilities of many students will remain undeveloped or underdeveloped.

Gifted education experts in a Delphi study assert that all teachers "should be provided with in-service training on the characteristics and needs of the gifted, including special populations, training in content and teaching strategies for gifted students with particular focus on addressing individual differences among students" (Cramer, 1991, p.89). The panelist's first priority issue was curriculum which they maintained "should include qualitatively different content, process skills, and product development "for gifted learners (Cramer, 1991, p. 90).

Meeting the needs of the gifted child requires a special educational approach that differs from approaches used with other populations of students. Gifted students require "more opportunities for divergent and associative thinking than most students” (Wright,1983, p.18). Gifted students also need programs that "provide pathways by which these students may venture away from the basic curriculum in areas in which they excel” (Strip, 2000, p. 70).

Gifted learners need "different pace of instruction, different content, and even different levels of application of heuristics and thought processes than many of their age mates”(Tomlinson, 1994, p. 179).

Not only should teachers take the time to recognize and understand each gifted student's needs, but teachers need to use this information to develop an individualized plan to nurture their above-average abilities. Teachers can easily implement these assignments if they make preparations to differentiate instruction and assignments for these gifted learners. In addition, 
teachers must have the appropriate gifted education training. Therefore, school districts must make it a priority to not only provide gifted education training to teachers, but also encourage all applicable teachers to attend.

In Iran, across the country, few educators have the necessary qualifications to work with gifted students and typical pre-service teacher training programs do not prepare teachers to meet the needs of gifted learners and so many teachers have not been adequately trained to identify or teach these exceptional children. To address this need, pervasive in-service staff development is necessary.

\section{Staff Development}

Staff development fulfills many purposes: job retention, role modification, support for school reforms, personal growth, and inspiration.

Gosfield(2002) pointed out that teachers are not able to gain expertise on gifted education by merely attending one-hour training sessions; instead, they must engage in high-quality professional development and invest their time, resources, and support in educating themselves about the special needs of gifted and talented students.

The conceptions of giftedness adopted by school systems shaped gifted education programming including identification processes, curriculum, and instruction (Miller, 2008).

The design and implementation of staff development to assist teachers in becoming more effective in meeting needs of gifted learners can be informed by what is known about adult development (Erikson, 2002, Kohlberg, 1971), adult learners (Knowles, 1980, 1984), and teacher development (Huberman, 1989, Steffy, Wolfe, Pasch \& Enz, 2000).

Teachers of middle school students need special abilities to work with the early adolescent child, teachers of gifted early adolescents need those same skills as well as additional skills in understanding and educating the gifted early adolescent child.

Clark (2002) declared that teachers of the gifted must know how to differ the pace of instruction, to accelerate or provide in-depth learning and advanced content because these are common needs of gifted students. Teachers must know how to develop high degrees of complexity and an interrelationship in the content, as well as provide novelty and enrichment to accept and extend intensity, divergence, and creative solutions. These special added teaching abilities are needed by teachers of gifted students because those students have specific needs, require additional challenges, and are different both in the quantity and the quality of their educational performance.

The opportunity to work with a teacher specially trained in educating the gifted child can positively affect the learning outcome for this unique group of students within the school environment. "The use of specialized personnel (i.e. special education, gifted education, technology, and so forth) is designed to provide direct support both to the students and the teachers" (Coleman, 2001, p. 21). 
Middle school teachers who understand that the middle school gifted child has unique academic social needs can assist the child in overcoming the problems that can arise for a gifted student at the middle school level (Tomlinson, 1999, Tomlinson \& Doubet, 2006).

A differentiated curriculum is intended to meet the needs, interests, and abilities of gifted students (California State Board of Education, 2005). Differentiation is a philosophy that allows educators to plan instruction to meet the needs of diverse learners to achieve targeted standards (Gregory \& Chapman, 2007).

It is important for middle school teachers to have professional development in teaching the gifted child. Teachers who have been trained to teach gifted and talented students are significantly more successful than teachers who have not been trained (Hansen\& Feldhusen, 1994). Trained teachers use concept-based approaches, foster more in-depth study of topics, deliver clearer presentations, use more appropriate pacing, allow for more student self-direction, foster more high-level thinking, focus more on creativity, and utilize more differentiated objectives (Hansen \& Feldhusen, 1994).

Collaboration between all participants in organizing and planning the program is of prime importance. Essential, also, is that the program be based on an assessment of the real needs and professional concerns of teachers. Staff development programs can be tailored to accommodate teachers' needs at different career stages. By offering more comprehensive staff development programs which use the stages of concern guidelines, well designed programs can be developed to help teachers become more effective.

\section{Purpose}

Since research has indicated that adult learners become more self-directed in their learning, and are more ready to learn when the content has immediate application to real life problems. (Knowles, 1980, 1984), it is important to involve teachers in planning for staff development programs. Therefore, the purpose of this study is twofold:

1. To determine the level of middle school teachers' desire for professional development in competencies outlined in Virginia's licensure requirements, identified in the literature, and reflected in the University of Virginia's courses in gifted education.

2. To Identify differences that may exist in the level of teachers' desire for professional development in competencies to teach gifted learners as they relate to gender, years of full time teaching, primary teaching assignment and in-service training hours completed in gifted education.

The demographic information requested in this study served as the independent variables and the bases of investigation as they relate to middle schoolteacher desire for professional development in gifted education.

The independent variables used in this study are rooted in the current thinking regarding adult development (Clark \& Caffarella,1999), adult learning theory, (Merriam,1993, 2005), gender differences (Levinson, 1986) and stages of teacher development (Fessler \& Christiansen, 1992 ). Thus, it seems reasonable that the independent variables included in this study: 
gender, primary teaching assignment, years of teaching experience and in-service training hours completed in education of the gifted might have some impact on or relationship to teacher desire for professional development in the identified competencies.

The dependent variables included the 28 competencies numbered as statements on the survey. The rationale for each of these variables is discussed:

\section{Gender}

Female teachers expressed higher levels of concern regarding their influence on students than did male teachers at the end of their third and fifth years of teaching, (Pigge \& Marso, 1997).

In a study of teacher perceptions of staff development, gender differences were found with significantly more males than females believing that teachers fail to incorporate the knowledge gained from in-service into their teaching performance (McBride, Reed \& Dollar, 1994).

Edwards and Green (1999) found significantly more male teachers dropping out of a staff development program than females. It seems possible that desire for staff development in teaching gifted learners might be different for males and females.

It would be advisable that providers of in-service be cognisant of results in some studies that suggest gender differences among teachers. It would be useful to the planners of professional development to be aware of these issues so they can implement strategies and incentives to assuage these problems.

O'Neil (2011) found no significant differences in teacher desire for professional development as related to gender.

\section{Teaching Assignment}

One might also expect to find a relationship between teacher desire for professional development in gifted education and one's teaching discipline (Starko, 2008). Starko (2008) asserts that, "it seems highly likely that the types of preparation that best facilitate gifted learners will be different for learners at different stages of development and/or different subject areas" (p. 690).

O'Neil (2011) found significant differences in four of the thirty-four competencies among teachers who differed in their primary teaching assignment.

\section{Years of Teaching Experience}

Watts (1980) suggested that formal and traditional forms of workshops and staff development courses are more valuable for teachers in the beginning and middle stages than for teachers in the later, mastery level. It seems plausible that a relationship exists between one's desire for staff development to teach gifted learners and years of teaching experience.

O'Neil (2011) found no significant difference in middle school teacher level of desire for staff development in competencies to teach G/T learners relative to the number of years of teaching experience. 


\section{In-service Training Hours}

Reis and Westberg (1994) found that teachers with staff development in gifted education were able to individualize for gifted learners more by utilizing curriculum compacting.

Westberg \& Daoust (2004) reported that teachers who have taken graduate courses in gifted education modify the curriculum more frequently.

O'Neil (2011) found no significant difference in middle school teacher level of desire for staff development in competencies to teach $\mathrm{G} / \mathrm{T}$ learners relative to the in-service training hours completed in gifted education.

\section{Research Questions}

The research questions for this study are the following:

1. What is gifted middle school teachers' level of desire for staff development in 28 competencies addressed in the licensure regulations for Virginia in gifted education, (8VAC20-542-310 gifted education add-on endorsement) substantiated in the literature, and reflected in the University of Virginia program matrices as important for teaching gifted and talented students?

2. Is there a difference in gifted middle school teachers' level of desire for staff development in 28 competencies relative to gender, primary teaching assignment, years of full time teaching experience, and hours completed in in-service training opportunities in gifted education? This question is divided into four sub-questions that follow:

2a.Is there a difference in middle school teachers' level of desire for staff development in 28competencies to teach gifted learners relative to gender?

2b.Is there a difference in middle school teachers' level of desire for staff development in 28 competencies to teach gifted learners relative to primary teaching assignment?

2c.Is there a difference in middle school teachers' level of desire for staff development in 28competencies to teach gifted learners relative to years of full time teaching experience?

2d.Is there a difference in middle school teachers' level of desire for staff development in 28 competencies to teach gifted learners relative to hours completed in in-service training in gifted education?

\section{Methodology}

\section{Research Design}

This study is an exploratory, non-experimental study of middle school teachers in Isfahan, Iran. "Descriptive research is appropriate when the researcher organizes, tabulates, and describes sets of data using frequencies, means, standard deviations and percentages to summarize data” (Pallant, 2003, p. 51). 


\section{Instrumentation}

To answer the research questions, a survey was used by the researcher to assess middle school teacher's desire for staff development in 28 competencies to teach gifted students.

In an effort to insure validity, the survey was based on Virginia's licensure requirements in gifted education and the competencies taught in the University of Virginia's courses in gifted education. The survey consisted of 28 competencies (items) utilizing a Likert scale, offering five response choices, requiring the respondent to rate his or her level of desire for professional development in the specified area, ranging from very low desire to very high desire. Before the scale was presented to the population surveyed, it was submitted to three professional educators with experience in gifted education for their advisement.

Then, a pilot study with five individuals from the population being studied was conducted to evaluate the clarity of directions and items on the survey. This resulted in the rewording of two competencies to enhance clarity.

The participants were asked to identify their gender, their primary teaching assignment, the number of years of full time teaching, and the number of in-service training hours completed in education of the gifted. These served as independent variables in the study.

The Statistical Package for the Social Sciences (SPSS 16) computer software was used to analyze the data for all the questions. For the purposes of SPSS, the gender and primary teaching assignment independent variables were classified as nominal, and the remaining 2 independent variables were classified as ordinal. The 28 dependent variables were classified as ordinal data.

\section{Reliability}

Reliability of the survey instrument was measured after the surveys were returned. The alpha should be positive at .70 or above, using Cronbach's alpha coefficient, to provide support for good internal validity (Pallant, 2003). The alpha level for this scale measured .96, suggesting high internal validity.

\section{Description of the Sample}

The population in this study included all middle gifted school teachers in Isfahan, Iran. Administrators were not included in this study. The 105subjects in the sample population were gifted middle school teachers in Isfahan, Iran. Frequencies and percentages were used to describe the data used as independent variables which include gender, primary teaching assignment, years of full-time teaching experience and hours completed in in-service training in gifted education. Table 1 provides a description of the subjects in the study. 
Table1. Frequencies, Percentages by Variable and Group/level for Subjects in 28 Competencies

\begin{tabular}{|c|c|c|c|c|}
\hline Variable & \multicolumn{2}{|c|}{ Groups/Levels } & Frequency & Percent \\
\hline \multirow{2}{*}{ Gender } & \multicolumn{2}{|c|}{ Male } & 47 & 44.8 \\
\hline & \multicolumn{2}{|c|}{ Female } & 58 & 55.2 \\
\hline \multirow{3}{*}{ Primary Teaching Assignment } & \multicolumn{2}{|c|}{ Basic science } & 51 & 48.6 \\
\hline & \multicolumn{2}{|c|}{ Humanistic science } & 28 & 26.6 \\
\hline & \multicolumn{2}{|c|}{ other } & 26 & 24.8 \\
\hline \multirow{4}{*}{ in-service training hours in gifted education } & 1 & None & 31 & 29.5 \\
\hline & 2 & $20-49$ & 52 & 49.5 \\
\hline & 3 & $50-100$ & 17 & 16.2 \\
\hline & 4 & $101+$ & 5 & 4.8 \\
\hline \multirow{4}{*}{ Years Teaching Experience } & 1 & $0-7$ & 8 & 7.6 \\
\hline & 2 & $8-15$ & 21 & 20 \\
\hline & 3 & $16-23$ & 51 & 48.6 \\
\hline & 4 & $23+$ & 25 & 23.8 \\
\hline
\end{tabular}

\section{Analysis of Data}

Question 1 states: Is there a significant difference in teachers' level of desire for staff development in 28 competencies addressed in the licensure regulations for Virginia in gifted education, as important for teaching gifted and talented students? To answer this question, the researchers organized, tabulated, and described the data using descriptive statistics including frequencies, means and percentages.

To further analyze the data, the researchers sought to identify competencies which were not significantly different from one another. This data would be useful to individuals who plan staff development. Identifying which competencies reflected the teacher's highest level of desire for in-service would allow a staff developer to choose a more favored topic of focus.

In this study the competencies were ranked according to mean scores. Table 2 reports the frequencies of responses and percentages for each level of desire (Very low desire, Low desire, Moderate desire, High desire and Very high desire) for all subjects who participated in the survey. In addition, Table 2 reports the mean for each competency along with its rank compared to the other competencies included in the survey.

Result showed that Item 4, "Knowing cognitive and social/emotional needs of gifted learners" had the highest mean score. Sixty subjects, more than for any other competency, rated their desire for professional development in this competency as "Very high desire."

Item 10, "Knowing the significance of historical events to the field of gifted education" had the lowest mean score. Item 10 also had the largest number of respondents $(n=10)$ who reported having "Very low desire" for professional development and the fewest number of 
respondents $(n=21)$ rating their level of desire for professional development in this competency as "Very high desire."

Table 2. Frequencies(n), Means, percents( \%)and Ranks of subject's desire for staff development in 28 competencies.

\begin{tabular}{|c|c|c|c|c|c|c|c|c|c|c|c|c|c|}
\hline \multirow[t]{2}{*}{ competency } & \multirow[t]{2}{*}{$\mathrm{N}$} & \multicolumn{2}{|c|}{$\begin{array}{l}\text { Very } \\
\text { Low } \\
\text { desire }\end{array}$} & \multicolumn{2}{|c|}{$\begin{array}{l}\text { Low } \\
\text { desire }\end{array}$} & \multicolumn{2}{|c|}{$\begin{array}{l}\text { Moderate } \\
\text { desire }\end{array}$} & \multicolumn{2}{|c|}{$\begin{array}{l}\text { High } \\
\text { desire }\end{array}$} & \multicolumn{2}{|c|}{$\begin{array}{l}\text { Very high } \\
\text { desire }\end{array}$} & \multirow[t]{2}{*}{ Mean } & \multirow[t]{2}{*}{ Rank } \\
\hline & & $\mathrm{n}$ & $\%$ & $\mathrm{n}$ & $\%$ & $\mathrm{n}$ & $\%$ & $\mathrm{n}$ & $\%$ & $\mathrm{n}$ & $\%$ & & \\
\hline 1 & 105 & 3 & 2.9 & 2 & 1.9 & 22 & 20.9 & 34 & 32.4 & 44 & 41.9 & 4.06 & 17 \\
\hline 2 & 105 & 1 & 1.0 & 0 & 0 & 16 & 15.2 & 34 & 32.4 & 54 & 51.4 & 4.28 & 4 \\
\hline 3 & 105 & 3 & 2.9 & 3 & 2.9 & 22 & 20.9 & 24 & 22.9 & 53 & 50.5 & 4.12 & 12 \\
\hline 4 & 105 & 1 & 1.0 & 1 & 1.0 & 12 & 11.4 & 31 & 29.5 & 60 & 57.1 & 4.38 & 1 \\
\hline 5 & 105 & 4 & 3.8 & 7 & 6.7 & 17 & 16.2 & 27 & 25.7 & 50 & 47.6 & 4.07 & 16 \\
\hline 6 & 105 & 5 & 4.8 & 9 & 8.6 & 23 & 21.9 & 23 & 21.9 & 45 & 42.9 & 3.9 & 22 \\
\hline 7 & 105 & 1 & 1.0 & 12 & 11.4 & 23 & 21.9 & 27 & 25.7 & 42 & 40.0 & 3.92 & 21 \\
\hline 8 & 105 & 4 & 3.8 & 14 & 13.3 & 27 & 25.7 & 31 & 29.5 & 29 & 27.6 & 3.64 & 26 \\
\hline 9 & 105 & 4 & 3.8 & 4 & 3.8 & 23 & 21.9 & 37 & 35.2 & 37 & 35.2 & 3.94 & 20 \\
\hline 10 & 105 & 10 & 9.5 & 14 & 13.3 & 35 & 33.3 & 25 & 23.8 & 21 & 20.0 & 3.31 & 28 \\
\hline 11 & 105 & 1 & 1.0 & 2 & 1.9 & 29 & 27.6 & 35 & 33.3 & 38 & 36.2 & 4.02 & 18 \\
\hline 12 & 105 & 2 & 1.9 & 3 & 2.9 & 37 & 35.2 & 26 & 24.8 & 37 & 35.2 & 3.86 & 23 \\
\hline 13 & 105 & 4 & 3.8 & 8 & 7.6 & 24 & 22.8 & 32 & 30.5 & 37 & 35.2 & 3.83 & 25 \\
\hline 14 & 105 & 5 & 4.8 & 8 & 7.6 & 16 & 15.2 & 33 & 31.4 & 43 & 41.0 & 3.96 & 19 \\
\hline 15 & 105 & 5 & 4.8 & 8 & 7.6 & 28 & 26.6 & 30 & 28.6 & 34 & 32.4 & 3.73 & 27 \\
\hline 16 & 105 & 4 & 3.8 & 5 & 4.8 & 19 & 18.1 & 28 & 26.7 & 49 & 46.6 & 4.08 & 14 \\
\hline 17 & 105 & 2 & 1.9 & 2 & 1.9 & 21 & 20 & 22 & 21.0 & 58 & 55.2 & 4.23 & 7 \\
\hline 18 & 105 & 1 & 1.0 & 5 & 4.8 & 18 & 17.1 & 29 & 27.6 & 52 & 49.5 & 4.20 & 8 \\
\hline 19 & 105 & 2 & 1.9 & 6 & 5.7 & 18 & 17.1 & 25 & 23.8 & 54 & 51.4 & 4.17 & 9 \\
\hline 20 & 105 & 1 & 1.0 & 1 & 1.0 & 28 & 26.7 & 27 & 25.7 & 48 & 45.7 & 4.14 & 11 \\
\hline 21 & 105 & 4 & 3.8 & 4 & 3.8 & 23 & 21.9 & 26 & 24.8 & 48 & 45.7 & 4.05 & 17 \\
\hline 22 & 105 & 4 & 3.8 & 2 & 1.9 & 35 & 33.3 & 21 & 20.0 & 43 & 41.0 & 3.87 & 24 \\
\hline 23 & 105 & 1 & 1.0 & 1 & 1.0 & 22 & 21.0 & 37 & 35.2 & 44 & 41.9 & 4.16 & 10 \\
\hline 24 & 105 & 1 & 1.0 & 1 & 1.0 & 15 & 14.3 & 29 & 27.6 & 59 & 55.2 & 4.34 & 2 \\
\hline 25 & 105 & 1 & 1.0 & 2 & 1.9 & 19 & 18 & 32 & 30.5 & 51 & 48.6 & 4.24 & 6 \\
\hline 26 & 105 & 1 & 1.0 & 3 & 2.9 & 18 & 17.1 & 24 & 22.9 & 59 & 56.2 & 4.3 & 3 \\
\hline 27 & 105 & 1 & 1.0 & 3 & 2.9 & 19 & 18.1 & 29 & 27.6 & 53 & 50.5 & 4.24 & 5 \\
\hline 28 & 105 & 2 & 1.9 & 6 & 5.7 & 19 & 18.1 & 29 & 27.6 & 49 & 46.7 & 4.11 & 13 \\
\hline
\end{tabular}




\section{Macrothink}

Question 2 states: Is there a relationship between each of the independent variables (gender, primary teaching assignment, years of full time teaching experience and hours completed in in-service training in gifted education) and the level of teacher desire to participate in staff development specific to each competency listed? In order to answer this question, four sub-questions were advanced to address each area separately.

Question 2a states: Is there a difference between males and females middle school teachers in their desire for staff development in strategies to teach G/T learners. To answer this question independent-samples t-tests were used, "an appropriate option when there is one categorical independent variable with two levels (e.g. males/females), and the researcher is interested in comparing the mean scores for significant differences on some continuous variable” (Pallant, 2003, p. 92). Table 3 summarizes the results of the independent-samples t-tests for the 28 competencies included in the survey.

Result showed that for Competency 16 "Assessing learning styles of gifted learners", 21 "Teaching gifted learners research methods used by real scholars", 22 "managing learning and/or independent study contracts effectively with gifted learners", 25 "Guiding gifted learners in metacognition" and 27 "Using problems having no single right answer for group or Individual investigation to encourage integration of multiple disciplines self-directed learning, and solution finding”, significant differences were found between males and female $(p<.005)$.

Findings suggest that female teachers showed significantly higher desire for professional development in competencies 16, 21, 22, 25 and 27. 
Table 3. Independent-samples t-test results of subjects' desire for staff development relative to gender

\begin{tabular}{|c|c|c|c|c|c|c|}
\hline \multirow{2}{*}{ item } & \multicolumn{2}{|c|}{ Males(n=47) } & \multicolumn{2}{|c|}{ Females $(n=58)$} & \multirow{2}{*}{$\mathrm{t}$} & \multirow{2}{*}{ Sig(2-talied) } \\
\hline & mean & SD & mean & SD & & \\
\hline 1 & 4.06 & 1.092 & 4.05 & 1.033 & 0.58 & 0.954 \\
\hline 2 & 4.34 & 0.788 & 4.22 & 1.125 & 0.599 & 0.550 \\
\hline 3 & 4.06 & 0.987 & 4.17 & 1.201 & -0.498 & 0.619 \\
\hline 4 & 4.34 & 0.867 & 4.41 & 0.937 & -0.412 & 0.681 \\
\hline 5 & 4.02 & 1.343 & 4.10 & 0.912 & -0.372 & 0.711 \\
\hline 6 & 3.94 & 1.071 & 3.86 & 1.290 & 0.315 & 0.753 \\
\hline 7 & 3.98 & 1.093 & 3.88 & 1.077 & 0.467 & 0.641 \\
\hline 8 & 3.51 & 1.101 & 3.74 & 1.163 & -1.035 & 0.303 \\
\hline 9 & 3.87 & 0.992 & 4.00 & 1.076 & -0.626 & 0.533 \\
\hline 10 & 3.54 & 1.100 & 3.21 & 1.295 & 1.009 & 0.315 \\
\hline 11 & 3.98 & 0.944 & 4.05 & 0.867 & -0.412 & 0.681 \\
\hline 12 & 3.85 & 0.955 & 3.86 & 1.146 & -0.053 & 0.958 \\
\hline 13 & 3.66 & 1.238 & 3.97 & 1.092 & -1.344 & 0.182 \\
\hline 14 & 3.81 & 1.209 & 4.09 & 1.081 & -1.241 & 0.217 \\
\hline 15 & 3.60 & 1.228 & 3.84 & 1.152 & -1.070 & 0.287 \\
\hline 16 & 3.83 & 1.222 & 4.28 & 0.933 & -2.121 & 0.036 \\
\hline 17 & 4.11 & 1.047 & 4.33 & 1.049 & -1.075 & 0.285 \\
\hline 18 & 4.06 & 0.987 & 4.31 & 0.922 & -1.320 & 0.190 \\
\hline 19 & 4.04 & 1.042 & 4.28 & 1.022 & -1.153 & 0.252 \\
\hline 20 & 4.04 & 0.977 & 4.22 & 0.859 & -1.013 & 0.314 \\
\hline 21 & 3.74 & 1.224 & 4.29 & 0.899 & -2.645 & 0.009 \\
\hline 22 & 3.53 & 1.365 & 4.14 & 0.981 & -2.643 & 0.010 \\
\hline 23 & 4.02 & 1.011 & 4.28 & 0.696 & -1.525 & 0.130 \\
\hline 24 & 4.17 & 1.090 & 4.48 & 0.755 & -1.732 & 0.086 \\
\hline 25 & 4.00 & 0.956 & 4.43 & 0.775 & -2.553 & 0.012 \\
\hline 26 & 4.15 & 1.042 & 4.43 & 0.797 & -1.571 & 0.119 \\
\hline 27 & 4.04 & 1.021 & 4.40 & 0.793 & -2.000 & 0.048 \\
\hline 28 & 4.00 & 1.123 & 4.21 & 0.932 & -1.032 & 0.305 \\
\hline
\end{tabular}

$\mathrm{df}=103$

Questions 2b states: Is there a difference between teachers whose primary teaching assignment is basic science (math, science), humanistic science (language arts, reading, social studies, and foreign language) or other (media specialist, guidance counselor, and their desire for staff development in each of the 28 competencies? 
A between-subjects one-way ANOVA was used to answer this question. The results for competencies 1 through 28 are reported in Table 4. No Significant differences $(p<.05)$ were found for the all competencies.

Table 4. Between-groups One-way ANOVA results of subjects' desire for staff development in 28 competencies relative to primary teaching assignment.

\begin{tabular}{|c|c|c|c|c|c|c|c|c|}
\hline \multirow[t]{2}{*}{ Competency } & \multicolumn{2}{|c|}{ Basic Science(n=51) } & \multicolumn{2}{|c|}{ Humanistic science(28) } & \multicolumn{2}{|c|}{ Other(28) } & \multirow{2}{*}{ F } & \multirow{2}{*}{ Sig } \\
\hline & Mean & SD & Mean & SD & Mean & SD & & \\
\hline 1 & 4.04 & 1.095 & 4.18 & 0.819 & 3.96 & 1.216 & 0.296 & 0.745 \\
\hline 2 & 4.08 & 1.197 & 4.39 & 0.685 & 4.54 & 0.706 & 2.193 & 0.117 \\
\hline 3 & 4.18 & 1.144 & 4.00 & 1.217 & 4.15 & 0.925 & 0.239 & 0.788 \\
\hline 4 & 4.27 & 1.060 & 4.46 & 0.744 & 4.50 & 0.707 & 0.696 & 0.501 \\
\hline 5 & 3.94 & 1.156 & 4.07 & 1.245 & 4.31 & 0.884 & 0.920 & 0.402 \\
\hline 6 & 3.82 & 1.381 & 4.00 & 1.122 & 3.92 & 0.845 & 0.204 & 0.816 \\
\hline 7 & 3.96 & 1.095 & 3.93 & 1.052 & 3.85 & 1.120 & 0.096 & 0.909 \\
\hline 8 & 3.67 & 1.260 & 3.75 & 1.041 & 3.46 & 0.989 & 0.461 & 0.632 \\
\hline 9 & 3.86 & 1.114 & 4.04 & 0.962 & 4.00 & 0.980 & 0.300 & 0.741 \\
\hline 10 & 3.20 & 1.167 & 3.54 & 1.319 & 3.31 & 1.192 & 0.707 & 0.496 \\
\hline 11 & 4.08 & 0.956 & 4.04 & 0.838 & 3.88 & 0.864 & 0.403 & 0.670 \\
\hline 12 & 3.73 & 1.218 & 4.07 & 0.900 & 3.88 & 0.864 & 0.974 & 0.381 \\
\hline 13 & 3.69 & 1.273 & 4.07 & 0.940 & 3.85 & 1.156 & 0.993 & 0.374 \\
\hline 14 & 3.84 & 1.239 & 4.18 & 0.945 & 3.96 & 1.148 & 0.775 & 0.463 \\
\hline 15 & 3.71 & 1.205 & 3.93 & 0.979 & 3.58 & 1.362 & 0.614 & 0.543 \\
\hline 16 & 4.08 & 1.163 & 4.07 & 0.858 & 4.08 & 1.197 & 0.000 & 1.000 \\
\hline 17 & 4.12 & 1.194 & 4.32 & 0.863 & 4.35 & 0.936 & 0.553 & 0.577 \\
\hline 18 & 4.04 & 1.038 & 4.39 & 0.832 & 4.31 & 0.884 & 1.473 & 0.234 \\
\hline 19 & 4.10 & 1.063 & 4.18 & 0.983 & 4.31 & 1.050 & 0.351 & 0.705 \\
\hline 20 & 4.12 & 0.931 & 4.04 & 0.922 & 4.31 & 0.884 & 0.630 & 0.535 \\
\hline 21 & 4.02 & 1.104 & 4.04 & 1.105 & 4.12 & 1.071 & 0.680 & 0.934 \\
\hline 22 & 3.75 & 1.324 & 3.96 & 1.261 & 4.00 & 0.849 & 0.509 & 0.603 \\
\hline 23 & 4.10 & 0.922 & 4.14 & 0.891 & 4.31 & 0.679 & 0.521 & 0.596 \\
\hline 24 & 4.35 & 0.934 & 4.25 & 1.110 & 4.42 & 0.703 & 0.237 & 0.790 \\
\hline 25 & 4.18 & 0.888 & 4.29 & 0.897 & 4.31 & 0.884 & 0.242 & 0.785 \\
\hline 26 & 4.22 & 0.986 & 4.32 & 0.983 & 4.46 & 0.706 & 0.615 & 0.543 \\
\hline 27 & 4.18 & 0.974 & 4.29 & 0.897 & 4.31 & 0.838 & 0.225 & 0.799 \\
\hline 28 & 4.06 & 1.121 & 4.18 & 0.983 & 4.15 & 0.881 & 0.148 & 0.863 \\
\hline
\end{tabular}

Question 2c states: Is there a difference among teachers with 0-7 years , 8-15 years, 16-23 years, or 23 + years of teaching experience and their desire for staff development in each of the 28 competencies? To answer the question, a between-groups one-way ANOVA test was used. The ANOVA results for the 28 competencies are presented in Table 5. No significant 
difference was found in middle gifted school teacher level of desire for staff development in 28 competencies to teach G/T learners relative to the number of years of teaching experience.

Table 5. Between-groups One-way ANOVA results of subjects' desire for staff development relative to years of teaching experience.

\begin{tabular}{|c|c|c|c|c|c|c|c|c|c|c|}
\hline \multirow[t]{2}{*}{ Competency } & \multicolumn{2}{|c|}{$\begin{array}{l}0-7 \quad \text { years of } \\
\text { teaching } \quad(n=8)\end{array}$} & \multicolumn{2}{|c|}{$\begin{array}{l}\text { 8-15 years of } \\
\text { teaching }(n=21)\end{array}$} & \multicolumn{2}{|c|}{$\begin{array}{l}16-23 \text { years of } \\
\text { teaching }(\mathrm{n}=51)\end{array}$} & \multicolumn{2}{|c|}{$\begin{array}{l}23+\text { years of } \\
\text { teaching }(\mathrm{n}=25)\end{array}$} & \multirow[t]{2}{*}{$\mathrm{F}$} & \multirow[t]{2}{*}{ sig } \\
\hline & Mean & SD & Mean & SD & Mean & SD & Mean & SD & & \\
\hline 1 & 4.14 & 0.900 & 4.10 & 0.889 & 4.14 & 1.020 & 3.84 & 1.313 & 0.464 & 0.708 \\
\hline 2 & 4.00 & 1.000 & 4.24 & 1.221 & 4.24 & 0.929 & 4.44 & 0.917 & 0.442 & 0.723 \\
\hline 3 & 4.43 & 0.976 & 4.05 & 1.244 & 4.20 & 1.020 & 3.96 & 1.241 & 0.453 & 0.716 \\
\hline 4 & 4.29 & 0.756 & 4.33 & 1.197 & 4.37 & 0.747 & 4.48 & 1.005 & 0.142 & 0.935 \\
\hline 5 & 4.14 & 1.069 & 4.19 & 1.030 & 4.06 & 0.988 & 4.00 & 1.472 & 0.120 & 0.948 \\
\hline 6 & 4.00 & 1.155 & 4.00 & 1.000 & 3.86 & 1.296 & 3.92 & 1.152 & 0.079 & 0.971 \\
\hline 7 & 3.86 & 0.900 & 4.00 & 1.049 & 3.86 & 1.040 & 4.04 & 1.274 & 0.187 & 0.905 \\
\hline 8 & 4.00 & 1.000 & 3.62 & 1.161 & 3.59 & 1.152 & 3.60 & 1.155 & 0.272 & 0.846 \\
\hline 9 & 4.00 & 1.000 & 3.76 & 1.261 & 4.00 & 0.980 & 3.92 & 0.997 & 0.267 & 0.849 \\
\hline 10 & 4.14 & 0.900 & 3.19 & 1.123 & 3.27 & 1.201 & 3.36 & 1.287 & 1.223 & 0.305 \\
\hline 11 & 4.14 & 0.900 & 3.86 & 0.793 & 4.08 & 0.868 & 4.00 & 1.080 & 0.340 & 0.797 \\
\hline 12 & 4.14 & 1.069 & 3.76 & 1.221 & 3.82 & 1.014 & 3.92 & 1.077 & 0.264 & 0.851 \\
\hline 13 & 4.14 & 1.069 & 3.95 & 1.071 & 3.75 & 1.163 & 3.80 & 1.323 & 0.332 & 0.802 \\
\hline 14 & 4.00 & 1.291 & 4.00 & 1.095 & 3.96 & 1.019 & 3.88 & 1.424 & 0.049 & 0.986 \\
\hline 15 & 4.29 & 0.951 & 3.71 & 1.384 & 3.69 & 1.049 & 3.86 & 1.376 & 0.538 & 0.657 \\
\hline 16 & 4.29 & 0.951 & 4.00 & 1.000 & 4.04 & 1.076 & 4.12 & 1.269 & 0.147 & 0.931 \\
\hline 17 & 3.43 & 1.813 & 4.24 & 1.044 & 4.27 & 0.874 & 4.32 & 1.108 & 1.464 & 0.229 \\
\hline 18 & 3.86 & 1.215 & 4.14 & 0.964 & 4.18 & 0.793 & 4.36 & 1.186 & 0.559 & 0.643 \\
\hline 19 & 4.14 & 1.215 & 4.10 & 1.261 & 4.16 & 0.880 & 4.24 & 1.128 & 0.076 & 0.973 \\
\hline 20 & 4.29 & 0.951 & 4.05 & 0.921 & 4.18 & 0.817 & 4.16 & 1.106 & 0.151 & 0.929 \\
\hline 21 & 4.71 & 0.756 & 4.05 & 1.117 & 3.94 & 0.968 & 4.04 & 1.338 & 1.039 & 0.379 \\
\hline 22 & 4.00 & 1.000 & 3.90 & 1.179 & 3.71 & 1.270 & 4.16 & 1.143 & 0.827 & 0.482 \\
\hline 23 & 4.43 & 0.787 & 4.24 & 0.831 & 4.06 & 0.759 & 4.20 & 1.080 & 0.534 & 0.660 \\
\hline 24 & 4.43 & 0.976 & 4.38 & 0.865 & 4.29 & 0.965 & 4.36 & 0.952 & 0.077 & 0.972 \\
\hline 25 & 4.29 & 0.756 & 4.10 & 1.044 & 4.25 & 0.717 & 4.32 & 1.108 & 0.260 & 0.854 \\
\hline 26 & 4.43 & 0.787 & 4.00 & 1.095 & 4.35 & 0.770 & 4.44 & 1.083 & 1.026 & 0.384 \\
\hline 27 & 4.00 & 1.291 & 4.05 & 0.921 & 4.25 & 0.796 & 4.40 & 1.041 & 0.718 & 0.544 \\
\hline 28 & 4.14 & 1.215 & 4.05 & 0.973 & 4.18 & 0.932 & 4.00 & 1.225 & 0.191 & 0.902 \\
\hline
\end{tabular}

Question 2d states: Is there a difference among teachers with No Hours, 20-49 hours, 50-100 hours, and 101 more hours of professional development completed in in-service training in gifted education in each of the 28 competencies? A between-groups one-way ANOVA test was used to determine if a significant difference $(p<.05)$ existed among the teachers in the 
different levels of in-service hours completed. Table 6 summarizes the results and no significant differences were found.

Table 6. Between-groups One-way ANOVA results for Subjects' desire for staff development relative to number of completed in-service training hours in gifted education.

\begin{tabular}{|c|c|c|c|c|c|c|c|c|c|c|}
\hline \multirow[t]{2}{*}{ Competency } & \multicolumn{2}{|c|}{$\begin{array}{l}\text { None } \\
(\mathrm{n}=31)\end{array}$} & \multicolumn{2}{|c|}{$\begin{array}{l}20-49 \quad \text { hours } \\
(n=52)\end{array}$} & \multicolumn{2}{|c|}{$\begin{array}{l}50-100 \quad \text { hours } \\
(\mathrm{n}=17)\end{array}$} & \multicolumn{2}{|c|}{$\begin{array}{l}100+\quad \text { hours } \\
(\mathrm{n}=5)\end{array}$} & \multirow[t]{2}{*}{$F$} & \multirow[t]{2}{*}{ sig } \\
\hline & Mean & SD & Mean & SD & Mean & SD & Mean & SD & & \\
\hline 1 & 4.23 & 0.990 & 4.04 & 0.969 & 3.94 & 1.249 & 3.60 & 1.673 & 0.645 & 0.588 \\
\hline 2 & 4.42 & 0.620 & 4.23 & 0.921 & 3.94 & 1.600 & 5.00 & 0.000 & 1.854 & 0.142 \\
\hline 3 & 4.00 & 1.095 & 4.15 & 1.073 & 4.29 & 1.312 & 4.00 & 1.000 & 0.291 & 0.832 \\
\hline 4 & 4.35 & 0.709 & 4.42 & 0.915 & 4.18 & 1.237 & 4.80 & 0.447 & 0.690 & 0.560 \\
\hline 5 & 4.06 & 1.263 & 4.00 & 1.155 & 4.06 & 0.827 & 4.80 & 0.447 & 0.771 & 0.513 \\
\hline 6 & 3.87 & 1.147 & 3.83 & 1.294 & 4.12 & 1.054 & 4.00 & 1.000 & 0.265 & 0.850 \\
\hline 7 & 3.94 & 1.093 & 3.98 & 1.075 & 3.65 & 1.115 & 4.20 & 1.095 & 0.523 & 0.668 \\
\hline 8 & 3.45 & 1.207 & 3.65 & 1.118 & 3.76 & 1.147 & 4.20 & 0.837 & 0.754 & 0.522 \\
\hline 9 & 3.81 & 1.195 & 3.98 & 0.960 & 4.00 & 1.000 & 4.20 & 1.095 & 0.316 & 0.814 \\
\hline 10 & 3.29 & 1.296 & 3.46 & 1.179 & 2.82 & 1.074 & 3.60 & 1.342 & 1.294 & 0.281 \\
\hline 11 & 3.97 & 0.836 & 4.02 & 0.939 & 3.94 & 0.899 & 4.60 & 0.894 & 0.768 & 0.515 \\
\hline 12 & 3.87 & 0.885 & 3.83 & 1.061 & 3.88 & 1.409 & 4.00 & 1.000 & 0.048 & 0.968 \\
\hline 13 & 3.74 & 1.032 & 3.77 & 1.131 & 4.00 & 1.458 & 4.40 & 1.342 & 0.620 & 0.604 \\
\hline 14 & 3.87 & 1.024 & 3.92 & 1.202 & 4.18 & 1.185 & 4.20 & 1.304 & 0.351 & 0.789 \\
\hline 15 & 3.68 & 1.222 & 3.73 & 1.173 & 3.76 & 1.200 & 4.00 & 1.414 & 0.108 & 0.955 \\
\hline 16 & 4.06 & 1.063 & 3.96 & 1.188 & 4.29 & 0.849 & 4.60 & 0.894 & 0.801 & 0.496 \\
\hline 17 & 4.23 & 0.920 & 4.17 & 1.133 & 4.18 & 1.131 & 5.00 & 0.000 & 0.962 & 0.414 \\
\hline 18 & 4.03 & 0.948 & 4.21 & 1.016 & 4.29 & 0.849 & 4.80 & 0.447 & 1.036 & 0.380 \\
\hline 19 & 3.94 & 1.153 & 4.17 & 1.024 & 4.35 & 0.862 & 5.00 & 0.000 & 1.830 & 0.146 \\
\hline 20 & 4.06 & 0.854 & 4.12 & 0.943 & 4.18 & 1.015 & 4.80 & 0.447 & 0.960 & 0.415 \\
\hline 21 & 3.81 & 1.046 & 4.06 & 1.162 & 4.24 & 0.970 & 4.80 & 0.447 & 1.500 & 0.219 \\
\hline 22 & 3.61 & 1.358 & 3.87 & 1.138 & 4.06 & 1.144 & 4.80 & 0.447 & 1.641 & 0.185 \\
\hline 23 & 4.03 & 0.912 & 4.27 & 0.866 & 3.94 & 0.748 & 4.60 & 0.548 & 1.335 & 0.267 \\
\hline 24 & 4.23 & 1.055 & 4.35 & 0.905 & 4.35 & 0.862 & 5.00 & 0.000 & 1.000 & 0.396 \\
\hline 25 & 4.06 & 0.929 & 4.25 & 0.860 & 4.41 & 0.939 & 4.60 & 0.548 & 0.899 & 0.444 \\
\hline 26 & 4.23 & 0.956 & 4.25 & 0.926 & 4.41 & 0.939 & 5.00 & 0.000 & 1.169 & 0.326 \\
\hline 27 & 4.13 & 0.806 & 4.25 & 0.947 & 4.24 & 1.091 & 4.80 & 0.447 & 0.773 & 0.511 \\
\hline 28 & 4.23 & 0.884 & 4.02 & 1.129 & 4.00 & 1.000 & 4.80 & 0.447 & 1.097 & 0.354 \\
\hline
\end{tabular}

\section{Conclusions}

Adults are self- directed (Knowles, 1980) and want to choose what they will learn. Thus, needs assessments are invaluable tools to find out what it is that adults are motivated to learn. 


\section{Ml Macrothink}

Research shows that in-service training that takes into account teachers' perceived needs results in strengthened participation and ownership ( Wood \& Thompson, 1993).

The data from this survey can be useful to staff developers in planning in-service opportunities that relate first to topics for which teachers' indicated the highest level of desire.

The results of this study could provide a starting point for someone planning professional development for middle school teachers.

Question 1 provided valuable information which might be the spring board for the beginning of a sustained program of in service for teachers in a particular locality. From the data recorded in the protocols, the staff developer learned precisely which competencies in education of the gifted the teachers most desired. The results of this study do not suggest that one competency is any more or less important than any other.

The results of this study in Question 2 show that variability in the participants' level of desire for professional development in competencies to teach gifted learners does exist. This variability, however, was not associated with primary teaching assignment, Years of Teaching Experience and hours completed in in-service training opportunities. Perhaps middle school teachers as a group tend to be more homogeneous with respect to their profession than they are in other areas of their lives. They all face the same kinds of students in their classrooms, and deal with similar kinds of constraints and frustrations in their workday. Only in gender were significant differences found, and then, in only five of the 28 competencies.

The results of this study can be used by staff developers to create in-service offerings that will be meaningful to teachers in this city. In areas that are not perceived by teachers as particularly desirable, staff developers will understand the need for creating convincing arguments for teachers to gain competency in those areas.

\section{The competencies list}

1. Understanding the evolution of concepts of intelligence and giftedness.

2. Knowing traits and characteristics of gifted learners.

3. Understanding justifiable principles and techniques in identification of gifted learners.

4. Knowing cognitive and social/emotional needs of gifted learners.

5. Development of advanced technological skills to enhance student performance.

6. Recognizing giftedness in special populations such as low income, culturally diverse, and physically disabled.

7. Creating a holistic approach to educating the gifted with parental and community involvement including establishment and maintenance of an effective advisory committee.

8. Knowing contributions of key leaders in gifted education whose work has direct bearing on the field. 
9. Understanding the issues surrounding underachievement in gifted learners.

10. Knowing the significance of historical events to the field of gifted education.

11. Understanding the relationship between definitions of giftedness, program philosophies, identification methods, and program services.

12. Understanding principles and application of acceleration in gifted education.

13. Analyzing and evaluating curricula models.

14. Knowing and understanding a variety of curriculum models.

15. Using curriculum compacting effectively with gifted learner.

16. Assessing learning styles of gifted learners.

17. Creating a learning climate responsive to the cognitive and affective needs of gifted learners.

18. Creating learning experiences for gifted learners relative to their readiness, interests, and preferred learning styles.

19. Developing sophisticated product assignments for gifted learners that extend independent learning and use varied modes of expression, including use of appropriate technology.

20. Using appropriate grouping strategies with gifted learners.

21. Teaching gifted learners research methods used by real scholars.

22. Managing learning and/or independent study contracts effectively with gifted learners.

23. Adapting my teaching and curriculum to foster analytical and critical thinking in gifted learners.

24. Adapting my teaching to elicit and nurture creativity in gifted learners.

25. Guiding gifted learners in metacognition.

26. Creating classroom interest and learning opportunities with resources beyond the textbook to accommodate needs of gifted learners.

27. Using problems having no single right answer for group or Individual investigation to encourage integration of multiple disciplines self-directed learning, and solution finding.

28. Developing strategies to manage a differentiated classroom including record keeping and grading rubrics appropriate for gifted learners.

\section{References}

California State Board of Education. (July 2005). Recommended Standards for Programs for Gifted and Talented Students: Retrieved May 24, 2012 from http://www.cde.ca.gov/fg/fo/r12/documents/gatestandards.doc. 


\section{Macrothink}

Journal of Studies in Education

ISSN 2162-6952

2012, Vol. 2, No. 4

Clark, B. (2002). Growing up gifted: Developing the potential of children at home and school. Upper Saddle River, NJ: Merrill Prentice Hall.

Clark, M., \& Caffarella, R. (1999). Theorizing adult development. In MC. Clark \& R.Caffarella (Eds.). New directions for adult and continuing education, 84, 3-8. San Francisco: Jossey-Bass. http://dx.doi.org/10.1002/ace.8401

Coleman, M. R. (2001). Middle schools: New trends and issues. Gifted Child Today, 24(4), 20-21.

Cramer, R. H. (1991). The education of gifted children in the United States: A Delphi study. Gifted child quarterly, 35(2), 84-91. http://dx.doi.org/10.1177/001698629103500207

Edwards, J. L., \& Green, K. (1999). Persisters vs. nonpersisters: Characteristics of teachers who stay in a professional development program. Paper presented at the annual meeting of the American Educational Research Association. Montreal, Quebec, Canada April 19-23. (Eric Document Reproduction Service No. ED 439 115).

Erickson, H. (2002). Concept-based curriculum and instruction: Teaching beyond the facts. Thousand Oaks, CA: Corwin Press.

Fessler, R., \& Christensen, J. (1992). The teacher career cycle: Understanding and guiding the professional development of teachers. Boston: Allyn \& Bacon.

Gosfield, M. (2002). Gifted all day long. Leadership, 32(1), 16-18 Hansen and Feldhusen (1994). Comparison of trained and untrained teachers of gifted students. Gifted child quarterly, 38(3), 16-21.

Gregory, G. H. \& Chapman, C. (2007). Differentiated instructional strategies: One size doesn't fit all (2nd Ed.), Thousand Oaks, CA: Corwin Press.

Huberman, M. (1989). The professional life cycle of teachers. Teachers College Record, 91(1), 31-57.

Knowles, M. (1980). The modern practice of adult education: From pedagogy to andragogy, revised and updated. Englewood Cliffs, NJ: Prentice Hall Regents.

Knowles, M. (1984). The adult learner: A neglected species (3rd ed.). Houston: Gulf Publishing.

Kohlberg, L. (1971). From is to ought: How to commit the naturalistic fallacy and get away with it in the study of moral development. In T. Mischel (Ed.), Cognitive development and epistemology, 151 -235. New York: Academic Press.

Levinson, D. (1986). A conception of adult development. American Psychologist, 41(1), 3-13. http://dx.doi.org/10.1037/0003-066X.41.1.3

McBride, R., Reed, J., \& Dollard, J. (1994). Teacher attitudes toward staff development: A symbotic relationship at best. Journal of Staff Development, 75(2), 36-41. 
Merriam, S. (1993). Adult learning: Where have we come from? Where are we headed? In S. Merriam (Ed.), New directions for adult and continuing education, 57, 5-14. San Francisco: Jossey-Bass. http://dx.doi.org/10.1002/ace.36719935703

Merriam, S. (2005). How adult life transitions foster learning and development. In M. Wolf (Ed.), New directions for adult and continuing education, 108, 3-14. San Francisco: Jossey-Bass. http://dx.doi.org/10.1002/ace.193

Miller, E. M. (2008). Conceptions of giftedness. In J. A. Plucker \& C. M. Callahan (Ed.), Critical issues and practices in gifted education: What the research says, 107-118). Waco, TX: Prufrock Press, Inc.

O'Neil, O .D. (2011). Survey of Middle School Teacher Desire for Staff Development Focused on Competencies to Teach Gifted and Talented Students. Retrieved May 24, 2012 from ProQuest Digital Dissertations. http://udini.proquest.com/view/survey-osisf-middle-school-teacher-pqid:2464027921.

Pallant, J. (2003). SPSS survival manual. Philadelphia, PA: Open University Press.

Pigge, F., \& Marso (1997). A seven year longitudinal multi-factor assessment of teaching concerns development through preparation and early years of teaching. Teaching and Teacher Education, 13(2), 225-235. http://dx.doi.org/10.1016/S0742-051X(96)00014-5

Regulations Governing the Review and Approval of Education Programs in Virginia. (2007). Effective September 21. Retrieved May 24, 2012 from http://www.doe.virginia.gov/teaching/regulations/regs_approval_education_programs_2011.p df.

Reis, S., \& Westberg, K. (1994). The impact of staff development on teachers' ability to modify curriculum for gifted and talented students. Gifted Child Quarterly, 8,127-135. http://dx.doi.org/10.1177/001698629403800306

Starko, A. J. (2008). Teacher preparation. In J Plucker \& C. Callahan (Eds.), Critical issues and practices in gifted education: What the research says, 681-694. Waco, TX: Prufrock Press.

Steffy, B., Wolfe, M., Pasch, S., \& Enz, B. (2000). Life cycle of the career teacher, 1-23. Thousand Oaks, CA: Corwin Press.

Strip, C. A. (2000). Helping gifted children soar: A practical guide for parents and teachers. Scottsdale, AZ: Great Potential Press.

Tomlinson, C. A. (1994). Gifted learners: The boomerang kids of middle school? Roeper Review, 16(3), 177-182.

Tomlinson, C. A. (1999). Mapping a route toward differentiated instruction. Educational Leadership, 57(1), 6-11. http://dx.doi.org/10.1080/02783199409553568

Tomlinson, C. A., \& Doubet, K. (2006). Smart in the middle grades: Classrooms that work for bright middle schoolers. Westerville, $\mathrm{OH}$ : National Middle School Association. 


\section{Macrothink}

Journal of Studies in Education

ISSN 2162-6952 2012, Vol. 2, No. 4

Virginia Register of regulations. (2007). 23(25), eff. September 21, Retrieved May 24, 2012 from: http://leg1.state.va.us/cgi-bin/legp504.exe?000+reg+8VAC20-542-310

Watts, H. (1980). Starting out, moving on, running ahead or how teachers' centers can attend to stages in teachers' development, Occasional paper No. 8. Far Wet Lab. for educational research and development, San Francisco, CA. National Institute of Education: Washington, DC.

Westberg, K., \& Daoust, M. (2004). The results of the replication of the classroom practices survey: Replication in two states. Storrs, CT: National Research Center on the Gifted and Talented, University of Connecticut.

Wood, F., \& Thompson, S. (1993). Assumptions about staff development based on research and best practice. Journal of Staff Development, 14(4), 52-57.

Wright, J. D. (1983). Teaching the gifted and talented in the middle school. Washington, D.C: National Education Association. 